\title{
What Did Hamlet (Not) Do to Offend Stalin?
}

\author{
Michelle Assay
}

\section{(2) OpenEdition \\ Journals}

Electronic version

URL: http://journals.openedition.org/shakespeare/3840

DOI: 10.4000/shakespeare.3840

ISSN: 2271-6424

\section{Publisher}

Société Française Shakespeare

\section{Electronic reference}

Michelle Assay, "What Did Hamlet (Not) Do to Offend Stalin? », Actes des congrès de la Société

française Shakespeare [Online], 35 | 2017, Online since 01 February 2016, connection on 01 May 2019.

URL : http://journals.openedition.org/shakespeare/3840; DOI : 10.4000/shakespeare.3840

This text was automatically generated on 1 May 2019.

(C) SFS 


\title{
What Did Hamlet (Not) Do to Offend Stalin?
}

\author{
Michelle Assay
}

1 Although it seems logical to assume that Stalin would not have sympathised with the Danish prince - and he would not have been the first political leader to have such an attitude $^{1}$ - there is no official documentation that could provide a factual backbone for his so-called Hamlet ban. Yet it has become received wisdom that Stalin not only hated Hamlet and its hero but accordingly banned any production in the Soviet Union. ${ }^{2}$

2 Stalin's animus towards Hamlet features in almost every study dealing with Shakespeare and Soviet political/cultural life. The myth of the ban in fact takes various shapes: at best it is nuanced by such modifiers as "tacit" ${ }^{3}$ or "virtual"; ${ }^{4}$ at its worst the myth takes the form of highly exaggerated claims, which usually disregard the historical facts, including actual productions of Hamlet during Stalin era. Here are two examples from quite respectable publications: "Theatrical performances of Hamlet were subsequently [to Mikhail Chekhov's 1924-5 production] banned until after Stalin's death in 1953", ${ }^{5}$ and "[in the 1940s] the play [Hamlet] had not been produced in the Soviet Union since Nikolai Akimov's zany version of 1932."6

3 Such statements can quickly be disproved. They disregard not only the provincial productions of Hamlet in the 1940s (for instance two in Belorussia directed by Valeri [also known as Valerian] Bebutov, one in 1941 at the Voronezh State Dramatic Theatre, and one in 1946 at the Iakub Kolas Theatre in Vitebsk) but also Sergei Radlov's rather wellknown 1938 staging, which due to its great success toured widely beyond Leningrad and Moscow, as far as the Urals, Sochi and Belorussia, to almost unanimously positive reviews. ${ }^{7}$ The explanation for such oversight is perhaps that given Radlov's subsequent imprisonment and internal exile, his name and that of his translator wife had disappeared from Shakespeare studies and criticism until well after their rehabilitation (posthumous in Anna Radlova's case) in 1957.

4 More ideologically motivated are over-exaggerations of the kind found in Solomon Volkov's widely debated concoction of Shostakovich's supposed memoirs. Volkov's Shostakovich is characteristically outspoken: "Of course, all the people knew once and for 
all that Stalin was the greatest of the great and the wisest of the wise, but he banned Shakespeare just in case. [...] For many long years Hamlet was not seen on the Soviet stage."

5 Volkov's mis-representations are no longer an issue in the scholarly world. ${ }^{9}$ It becomes more frustrating when a Russian theatre scholar of the stature of Anatoly Smeliansky presents the myth of Stalin's Hamlet ban in tones that similarly brook no disagreement: "Stalin, for obvious reasons, intensely disliked the play [Hamlet] and banned it at the MKhAT [Moscow Art Theatre] after it had been in rehearsal for a long time in Pasternak's translation." ${ }^{10}$ I shall return shortly to the MKhAT affair. But apart from the lack of reference to any source and the exaggerated tone, an even more obvious mistake is Smeliansky's immediately following claim that Okhlopkov's 1954 Hamlet was the first post-Stalin production of the play ${ }^{11}$ - both Grigory Kozintsev's Hamlet at the Alexandrinsky Theatre in St Petersburg and Radlov's at Daugavpils in Latvia predated Okhlopkov's. I shall also return to these post-Stalin productions, just before the end of this article.

Yet here, Smeliansky, as most other more scholarly studies, does at least refer back to one of the prime sources for the myth of the banning of Hamlet: namely the doomed MKhAT production of the early 1940 s.

\section{Moscow Art Theatre's Hamlet: To ban or not to ban?}

Probably the closest point, in Western literature at least, to the source of this Soviet whisper seems to be a statement by the theatre scholar Nikolai Chushkin and - for Western readers - Arthur Mendel's quoting of it: "It is enough to recall that an offhand remark by Stalin in the spring of 1941 questioning the performance of Hamlet at that time by the Moscow Arts Theater was sufficient to end rehearsals and to postpone the performance indefinitely." ${ }^{12}$

Before proceeding to the facts related to this story, we need to put Chushkin's remark in its appropriate context. Chushkin offers no reference, but his statement is preceded by a fairly incontestable observation regarding Soviet wartime theatre and the public's need for morale-boosting, or at the very least for active, optimistic plays as opposed to passive, pessimistic ones. Chushkin recollects how "shortly before the Great Fatherland War", and as the nation prepared itself to fight the Nazis, there were increasing arguments regarding the Soviet audience's need for an active hero. ${ }^{13}$ However, this in itself does not imply the complete absence of Hamlet and/or allusions to it (for example Yorick's skull or Hamlet's monologue) from the Soviet stage. From 20 to 30 April 1944, for instance, Yerevan celebrated the Bard's $380^{\text {th }}$ birthday in style, with an instalment of the All-Union Shakespeare Conference and accompanying festivals including a production of Hamlet. ${ }^{14}$

But despite such documented instances of the presence of Hamlet on the Soviet stage, the myth of Stalin's disapproval has persisted. With no actual reference to be found in the archives (including that of the Moscow Art Theatre) ${ }^{15}$ literary historian Dmitri Urnov's article, "How did Stalin ban Hamlet?", ${ }_{16}^{16}$ is perhaps the only example of an in-depth investigation. Urnov agrees that the aborted production of Hamlet at the Moscow Art Theatre in the early 1940s, and in particular the rumours that surrounded it, were the main point of origin. This was of course no ordinary production: apart from the iconic venue of the Moscow Art Theatre, this staging featured the collaboration of such 
luminaries as Vladimir Nemirovich-Danchenko (main supervisor), Vasilii Sakhnovskii (director), Boris Pasternak (translator), Vissarion Shebalin (composer), Vladimir Dmitriev (artist designer) and Boris Livanov (leading actor).

10 In copious detail, and with many added commentaries, often in the form of rhetorical questions, Urnov offers an overview of the historical facts, as well as reports and reminiscences of such figures as Livanov regarding this production and its fate. The story comes to us second hand: Urnov retells it as reported by the lead actor: ${ }^{17}$

In the 1940s, at a reception in the Kremlin [...] Boris Nikolaevich [Livanov] is asked to [...] go to a special hall where "the one whom everyone knows" is present. Zhdanov is at the piano, playing. Stalin enters [...]. "What is the [Moscow Art] Theatre working on these days?" asked Stalin; learning that the Theatre is going to stage Hamlet, Stalin then states: "But Hamlet is weak" [...] "But our Hamlet is strong, comrade Stalin", answered the actor preparing the role. "This is good," replies Stalin, "because the weak get beaten." 18

If this encounter resulted in the rumours regarding the "ban", that can only be explained "in the spirit of the Stalin time [...] then it was possible to draw any conclusions in accordance with one's goals, or as a result of one's fears or risks." Hence the Theatre's official statement regarding the encounter quoted Stalin as saying: "it was great to speak to a thinking [mysliashchim] artist." Such vague phraseology typically allowed room for many different interpretations, as dictated by individual and collective fear. "This [fear] was in the air and we breathed this air", adds Urnov.

11 Evidently the story of Stalin's disapproval was also in the air, because later it was re-told by Isaiah Berlin, among others, albeit in a different version, where Stalin had supposedly described Hamlet as decadent and not suitable for staging. ${ }^{19}$ As Alexei Semenenko observes, the popularity of such rumours was inevitable, since it fitted in with "the vein of the mythology surrounding Stalin". ${ }^{20}$

Urnov, however, goes on to argue - convincingly - that the production of Hamlet at the Moscow Art Theatre was halted not by Stalin but rather by many unfortunate circumstances and much internal tension within the Theatre itself. The outbreak of the War and the arrest of the director, Vasilii Sakhnovsky, raised the first hurdles. Yet once the Theatre returned from the wartime evacuation, rehearsals for Hamlet continued under the supervision of Nemirovich-Danchenko himself. For him, as for Stanislavsky and Meyerhold, Hamlet was a lifetime project destined never to be realised. ${ }^{21}$ The accounts of Nemirovich-Danchenko's work on the MKhAT production suggest that the elderly director was desperate to realise his Hamlet dream. Among the materials in the personal collection of the theatre director and critic Arkadii Katsman, there are reproductions of Dmitriev's sketches and models for various scenes. One of them, depicting the setting for the first act, is curiously very similar to Natan Altman's design for Grigori Kozintsev's 1954 production. It has a note on the back of the photo: "This version was not taken up by N.-Danchenko. This is due to its being too cumbersome (gromozdko), gloomy (mrachnyi) and pessimistic. Dmitriev made other more optimistic sketches." 22

Then came Nemirovich-Danchenko's demise in 1943, which with hindsight sounded the death-knell for this production. At first the Theatre continued with rehearsals and preparations, seemingly determined "to create a show worthy of the memory of the great Master [Nemirovich-Danchenko]". ${ }^{23}$ Here Urnov's account differs from Livanov's reminiscences. According to the former, Nemirovich-Danchenko's replacement, Nikolai Khmelev, was dead set against this production of Hamlet and even told Boris Livanov that "you shall play Hamlet over my dead body". ${ }^{24}$ 

his mother as receiving in early 1945 a gift from a troupe of English actors headed by John Gielgud, consisting of "a recording of two monologues from Hamlet read by Gielgud. He dedicated his performance to [...] 'my friend Boris Livanov, who is now working on Hamlet"'. ${ }^{25}$ According to Vasilii Livanov, his father's working notebooks of this time confirm that he and his friend Pasternak were hard at work trying to adjust the translation to the acting and to the requirements of the Theatre. It could be argued, incidentally, that this set a trend for Pasternak, who later created at least twelve different versions of his translation of the tragedy. ${ }^{26}$

As for the music, a letter from Shebalin to his wife on 18 June 1943 indicates that he had just "signed the contract for composing music to Hamlet at the MKhAT". In December 1944 he mentioned completing his score, avowing that "this work has been interesting and most significant for me." ${ }^{27}$

Despite all efforts, the MKhAT production seems to have come to a complete standstill by 1945, when Hamlet was replaced by Ivan the Terrible, a play about the medieval Russian tsar by Alexei Tolstoy, which was premiered in 1946. This turn of affairs did not pass without comment. In the same year Pasternak, whose other Shakespearean translations apparently had no better chance of being staged in major theatres, wrote directly to Stalin. In this curious letter, which seemingly remained unanswered, after complaints about various personal, domestic and family problems, Pasternak reminded Stalin of his work on translating Shakespeare "for the past five years" and asked:

Is it possible for the Committee on Artistic Affairs [Komitet po delam iskusstv] [the body that later that year became the Ministry of Culture] to drop a hint to theatres, so that they could be content with their own taste and stage them [i.e. these plays], if they like them, without awaiting any additional instructions [ukazaniia]? Because in theatres, and not only there, everything that lives only by itself and not thanks to some additional recommendations or sanctions is put aside. This is what happened to Hamlet at MKhAT, whose path was crossed by the modern play, Ivan the Terrible. ${ }^{28}$

Semenenko suggests that by calling a play about Ivan the Terrible "modern", Pasternak was ironically alluding to Stalin's "ongoing campaign of mythologization of the first Russian tsar". ${ }^{29}$ Be that as it may, taking an ironic tone in a letter to Stalin would have been a dangerous game to play.

\section{Ivan the Terrible: A Russian Hamlet?}

The names of Ivan the Terrible and Hamlet were soon to be brought together in a different context, which could be considered as the second source for the by then wellknown attitude of Stalin towards the Danish prince. The two parts of Sergei Eisenstein's planned epic trilogy on the life and times of Ivan the Terrible had contrasting fates. The first, released in 1944, enjoyed great success and was awarded the coveted first-class Stalin prize, while the second, filmed in 1946-1947, was famously met with severe criticism from Stalin and had to wait until 1958 to be released in public cinemas. In February 1947 the film-maker and the actor of the title-role, Nikolai Cherkasov, were summoned to a meeting with Stalin, Zhdanov and Molotov at the Kremlin, during which they were given a fierce dressing-down and driven to self-denunciation. ${ }^{30}$

Stalin formulated one of his main criticisms using Hamlet as an analogy: "The tsar comes out in your film as indecisive, like Hamlet. Everyone suggests to him what should be done,

Actes des congrès de la Société française Shakespeare, 35 | 2017 
but he can't make a decision himself." ${ }^{11}$ Despite the abundant presence of bloodshed and carnage, Stalin complained that Eisenstein had failed to depict the cruelty of Ivan and "why it was essential to be cruel." 32

There is no doubt about Eisenstein's debt to Elizabethan revenge tragedy as a genre and to Shakespeare's appropriation of it in his Hamlet in particular. Katerina Clark provides several instances from Eisenstein's writings, life and works in this regard..$^{33}$ However, despite the multi-layered structure of Eisenstein's film and its problematic reception, few mentions of Stalin's criticism go beyond the face-value of the Ivan/Hamlet comparison. Those that do are most revealing. Semenenko, for example, observes that this comparison reveals above all how Stalin's model of history differed from the one depicted by Eisenstein, which was "based, among other factors, on the Shakespearean model of tragedy". Instead of using "the historic events as a background for the characters' lives", Eisenstein focused on "Shakespearean tragedy, in which psychology and history are fused." ${ }^{34}$ This is confirmed by Molotov's criticism of Part 2 of Ivan the Terrible regarding "the stress on psychologism, on the excessive emphasis of inner psychological contradictions and personal sufferings." ${ }^{35}$ For her part, Clark identifies the source of "Eisenstein's emphasis on the way irrational psychological forces drove Ivan" in a passage from T.S. Eliot's essay on Hamlet and his psychological motives in The Sacred Wood, a work that Eisenstein himself refers to in his writings. ${ }^{36}$

With the drastic change of cultural climate from relative artistic freedom during the Great Patriotic War to the start of the anti-formalist campaign that ensued, it seems there was no room for an Ivan depicted as a tragic character of a Shakespearean stamp, rather than as a mythical figure and a "great and wise ruler". ${ }^{37}$

21 Stalin's Hamletised reception of Ivan the Terrible was emblematic of the drastic post-war changes in the political and cultural climate, following the legitimisation of Soviet power by victory in the Great Patriotic War. Eisenstein's film and Stalin's reaction to it, including his famous criticism of its depiction of the tsar, are often quoted in relation to the post-war cultural purges and the period that has come to be known as the Zhdanov Affair [Zhdanovshchina] after the second secretary of the Communist Party, Andrey Zhdanov (1896-1948). But in fact, Zhdanov himself died before the full consequences of the anti-formalism campaign unfolded, and before anti-cosmopolitanism showed its teeth. As Dobrenko and Clark observe: “Zhdanov's role [...] was not decisive. Unquestionably, it was Stalin who not only initiated the various decisions but also directly dictated and pronounced them." ${ }^{38}$

The Kremlin meeting of 26 February 1947 came six months after the decrees of the Central Committee against the journals Leningrad and Zvezda, the first of three decrees of that year establishing the policy of cultural repression and the official start of the Zhdanov era. ${ }^{39}$ As the editors of Soviet Culture and Power show, referring to the materials from the Central Committee archives, Zhdanovism was nothing new and was not preceded by any kind of "thaw". In essence, the resolutions of the years 1946-1948 "merely made public what had been known to a narrow circle of writers and had been concealed from the broad public." ${ }^{40}$ Furthermore these decrees, which were just "ordinary 'censoring' resolutions" were simply "symbolic documents marking the new status of the state" and its public function of exhibiting itself. ${ }^{41}$ In theatre too, there was a natural continuation of the pre-war campaign for Socialist Realism, and theatrical Zhdanovism was merely officialised by the second decree of the Party Central Committee, issued on 16 August 1946 and titled "About the Repertoire of 
the Dramatic Theatres and the Means of Improving It". According to this "the principal defect of the present dramatic repertoire is that plays by Soviet authors on the contemporary themes have actually been crowded out of the country's leading theaters." ${ }^{42}$ Similar criticism had already featured in closed discussion sessions of Radlov's Theatre in the late 1930s; but if Radlov had managed to partially ignore them then, this time the Central Committee resolved to oblige the Committee on Artistic Affairs to ensure "the production by every drama theatre of no fewer than two or three new plays annually of high ideological and artistic standards on present-day Soviet themes." ${ }^{43}$ The changes to the administrative system of the theatres and the appearance of the new role of the deputy artistic director in charge of literature (Zavlit) reduced the artistic freedom of the theatre producer and "further reinforced the outside control and complicated any diversions. ${ }^{\prime 4}$ All this, and particularly the resolutions, should be viewed, as Dobrenko puts it, as "ideological warm-ups" and "prelude" to the rising campaign of "struggle against anti-cosmopolitanism" and "preparation for a new wave of terror." 45

Curiously, none of these factors seem to have resulted in Shakespeare being dethroned, even if Soviet Shakespearean priorities at this time shifted noticeably from stage to page. There is good evidence to suggest that in post-war years the Bard was "generally tolerated and even generously subsidized by Communist authorities but, at the same time, strictly controlled." Bearing the seal of approval of Marx, Engels and Lenin, Shakespeare was indeed an attractive subject for schools and research institutes and provided "an ideal classic to reach the widest strata of readers and audiences and thus to bridge the gap which had frequently developed between modern art and the people." ${ }^{\prime 6}$ Moreover, in the immediate post-war years, Shakespeare was briefly used as "a link between Russia and the West". In this regard, Mikhail Morozov played a defining role. He contributed "a few brief notes on Shakespearean events in Russia" to the American Shakespeare Association Bulletin, ${ }^{47}$ and his booklet Shakespeare on the Soviet Stage (translated into English) was published in England, opening with a fulsome introduction by John Dover Wilson. ${ }^{48}$ Surprisingly, perhaps, the booklet gave no sign of any exploitation of Shakespeare for ideological means and propaganda. Instead it offered a brief history of Russian adaptations and translations of Shakespeare plays since the $18^{\text {th }}$ century, followed by a chapter on recent productions, and ending with a declaration, admired by Dover Wilson, of the necessity for a close relationship between scholars and practitioners. However, when it came to the inevitable mentioning of Radlov's productions, Morozov managed to avoid any reference to the name of the theatre director, who was at this point considered a non-person. Morozov used instead the name of the leading actors as a means of identifying these specific adaptations.

The official accounts of theatre repertoires of the wartime and late Stalinist period, published during the "thaw" ${ }^{49}$ are, as Makaryk observes, quite sketchy and gloss over many plays that were feared to be problematic. ${ }^{50}$ With the rumours of Stalin's attitude towards Hamlet already in the air, it is not surprising that the few productions of Hamlet that did take place received minimal attention. For example, Valerian Bebutov's 1946 Hamlet at the Kolas Theatre of Vitebsk received very little comment beyond its being in line with the tendency of the time to present Hamlet as fighter (Gamlet-bortsa).$^{51}$ There were at least two more Hamlet-related events in the same year, both in the form of a composition (kompozitsiia) for a single performer, and both in Moscow. The main actor of Radlov's Hamlet, Dmitrii Dudnikov, is reported to have presented his composition of Hamlet during one of the evenings of the annual Shakespeare Conference..$^{52}$ The other 
one-man Hamlet event was organised by actor and musicologist, Aleksandr Glumov, at the Club of Moscow State University and at the Polytechnic museum in September 1946 and on 4 January 1947. Surviving posters of these events advertise them as "Concert with reading of a composition based on tragedy of Hamlet by Shakespeare, with music by N.N. Rakhmaninov [sic!] arranged for string quartet." 53 The accounts of the "protokol" and discussion (obsuzhdenie) at Moscow University show that Glumov included the monologues as well as the main characters of the tragedy and succeeded in providing different nuances for each of them. ${ }^{54}$ The translation Glumov chose for his monospectacle was that of Pasternak, and by doing so he offered the first ever Moscow public performance and quasi-staging of this text. Pasternak himself attended the premiere, and it was after this performance that he created the first draft of his poem "Hamlet", which not only appears at "the opening bars of the coda" to Doctor Zhivago but also marks the start of the author's first phase of intensive work on the beginning of his iconic novel. ${ }^{55} \mathrm{In}$ a similar way to Glumov's performance with its multi-tiered central figure, the lyric persona of Pasternak's "Hamlet" is "a composite of at least five strata - Pasternak, Zhivago, an actor portraying Hamlet, Hamlet himself, and Christ." ${ }^{56}$ A similar complexity was embodied in the Soviet bard of the 1970s, Vladimir Vysotsky, whose guitar accompaniment to his "recital" of the as-yet-unpublished poem of Pasternak provided an ideal opening for Yuri Lyubimov's canonic production of Hamlet at the Taganka Theatre (1971-1980). ${ }^{57}$

26 Admittedly, and notwithstanding the previously mentioned productions of Hamlet and the continuation of related scholarship, the account of registered Shakespeare productions of the post-war and late-Stalinist period reveals a clear preference for comedies, particularly in the years immediately following the war; among the tragedies, Othello was the front runner, with as many as 52 productions between March 1945 and February 1953; Macbeth and Richard III were the least performed plays, apart from those not performed at all..$^{58}$

The year 1948 saw the extension of the Zhdanovshchina to composers ${ }^{59}$ and the assassination of the actor, Solomon Mikhoels, soon to be followed by the anticosmopolitan campaign brought about in January 1949 "by circumstances that had arisen in Stalin's circle after the unexpected death of Zhdanov." ${ }^{\circ 0}$ During this critical period, it was not Shakespeare but supposed Western-style attitudes towards his scholarship that came under attack, including works of Mikhail Morozov that were deemed to be under Western influence, particularly his 1947 project Shekspirovskii sbornik, this being the proceedings of the annual Shakespeare Conference held by the Shakespeare Department of the All-Russian Theatre Society (VTO). ${ }^{61}$ It was not the subject matter or the mere fact of writing about a foreign author that came under criticism, but Morozov's "Western" approach to Shakespeare scholarship and his lack of insistence on the superiority of Soviet Shakespearology. In subsequent articles, Morozov tried to redeem himself by attacking "bourgeois" critics and by accusing the West of dissociating Shakespeare from real life and realism, insisting that Shakespeare's humanism and realism could only be revealed in Soviet productions, where the heroes are not abstract. ${ }^{62}$

Following these attacks, and while politically correct "Soviet Shakespearology" was being supplanted by commentaries by Pushkin and Vissarion Belinski, there were also translations, often reprinted in anthologies. In this regard Pasternak had his fair share, with his translations being published in various guises ${ }^{63}$ Meanwhile, the next volume of Shekspirovskii sbornik had to wait until after Stalin's death in 1953, by which time Morozov 
was also dead and had been replaced by Aleksandr Anikst as the new face of Soviet Shakespeare scholarship. From this point on Soviet Shakespearology gradually separated along three distinct lines, namely Anikst and his school; the philosophical approach typified by Lev Vygodskii; and Kozintsev's fusion of a close reading of Shakespeare text with practical directorial experience. ${ }^{64}$ This diversity of approach was not sharply antagonistic, as had been the case prior to death of Stalin, but it represented a clear move away from the "conflictlessness" of the late Stalin era. At the same time, sites of sociopolitical and artistic contention moved from affirmation of the status quo towards critique of it, with Hamlet as a potential instrument of such critiques.

\section{Post-Stalin Hamlet Fever}

There was at least one other contributing factor to the longevity of the myth of Hamlet and Stalin: the Hamlet fever that took over Soviet theatres following Stalin's death, which is now well known and widely quoted in Western and Russian literature, even if many nuances of this term are commonly ignored. ${ }^{65}$ It could be argued that the sudden onset of Hamlet productions meant that they might have been held back while Stalin was alive. Senior Russian Shakespeare scholar, Alexei Bartoshevich, himself an advocate of the idea of the tacit/unofficial Stalin ban, explains the phenomenon rather more subtly, by suggesting that in the history of Hamlet's stage life there has been an alternation of Hamletian and non-Hamletian eras. ${ }^{66}$ The former is when all political, social and historical factors are aligned in such a way as to make society - or more precisely a generation within a given society - open and ready for new Hamlets. Accordingly 1954 was a Hamletian time, as were the 1970s, when Vladimir Vysotsky's Hamlet took both Soviet and international stages by storm.

In any case, the myth of Stalin's banning of Hamlet was one that fitted well with Cold War agendas. And over time the Stalin-and-Hamlet saga seems to have become a kind of a marketing tool for new productions of the tragedy by any Central/Eastern European company that tours to the West. ${ }^{67}$ It could probably even be argued that regardless of its authenticity the myth has stimulated creative responses, such as the aforementioned cascade of productions in 1954 and those productions and adaptations that incorporated criticism of the Stalinist Terror and Repressions, for example (arguably) Kozintsev's 1964 film and (unarguably) Sergei Slonimsky's 1991 opera. Paradoxically, some of the most politically repressed artists admit a "debt" to those conditions, as, for instance, the Lithuanian Andrius Mamontovas: "I miss those secret messages... there were always little secret messages from the artist to the audience. But there's no need for that now because you can say what you want openly - it's more entertainment now." ${ }^{68}$ If he had said mere entertainment, it might have made the same point even more strongly.

\section{Conclusion: Hamlet or Hamletism?}

The Soviet Hamlet landscape as it has been passed down to us features several items of received wisdom that reflect reductionist views on the cultural climate of the Stalin era in general. ${ }^{69}$ The issue of Stalin's supposed "ban" on productions of Hamlet, is a prime example in this regard. Gaining some clarity about its status opens the way to subtler accounts of what motivated artists in the late- and post-Stalin eras. At the same time, the fact that it was acted on at the time as though it was a reality rather than fiction itself 
offers an insight into Russian society and culture at the time. After all, as Bartoshevich and others have repeatedly noted, any interpretation of Hamlet in Russia offers a mirror that reflects the specifics of a society at that given moment. ${ }^{70}$

No study of Hamlet's afterlife could be complete without a mention of "Hamletism". Although the genesis of the term remains unclear, ${ }^{71}$ in scholarly terms, the problem of Hamletism could be described in nuce as "a tendency to interpret Hamlet the character as a symbol (a proper name turns into a common noun) which embodies certain philosophical, social, psychological, or political characteristics and represents a certain type, or behavior." ${ }^{22}$ In other words, according to time and place, new symbolic meanings are assigned to Hamlet the character, which in turn influence the interpretation of Hamlet the play and thus keep the text alive for the appropriating nation/era. However, some of these meanings have proven persistent (globally or locally) throughout history. Accordingly, Hamlet as a "metaphoric referent", by common consent includes "semantic fields of alienation, opposition, doubt, melancholy, oppression". ${ }^{73}$ Rooted in $19^{\text {th }}$-century Romanticism, the most prevailing connotation of Russian Hamletism indeed implies struggle with the accursed question of "To be or not to be", which became the thematic core of the play and its interpretations. And it was certainly this view of the tragedy to which Stalin reacted negatively.

This notion of Hamletism, which was overwhelmingly present in Mikhail Chekhov's 1924 production, had already been described as undesirable by several Soviet theatre directors in the 1930s, notably by Nikolai Akimov in his notorious 1932 staging with Shostakovich's music. ${ }^{74}$ Accordingly, almost all productions of Hamlet from that point prior to the death of Stalin avoided the problem of Hamletism or else directly attacked it, presenting the Danish prince as an active hero and warrior, ${ }^{75}$ whereas the two most important immediately post-Stalin productions of Hamlet (Kozintsev's and Okhlopkov's) reverted to the portrayal of a man who was capable of doubting, pessimism and other notions associated with the $19^{\text {th }}$-century "Hamletism". Indeed, going back to Stalin's Ivan the Terrible and Hamlet analogy, we realise that by describing Hamlet as a weak-willed man, Stalin was in fact revealing that his understanding of Hamlet had its roots in the $19^{\text {th }}$ century Hamletism - Hamlet as a weak-willed, indecisive and passive tragic figure. ${ }^{76} \mathrm{Ban}$ or no ban, then, it seems plausible at least that it was Hamletism, rather than Hamlet or even Hamlet, that offended Stalin.

\section{NOTES}

1. Aleksei Semenenko, "Pasternak's Shakespeare in Wartime Russia", in Irena Makaryk and Marissa McHugh (eds), Shakespeare and the Second World War: Memory, Culture, Identity, Toronto, University of Toronto Press, 2012, p.157.

2. See, for example, David Bevington, Murder Most Foul: Hamlet through the Ages, New York, Oxford University Press, 2001, p. 151.

3. Irena Makaryk, "Wartime Hamlet", in Makaryk and Joseph G. Price (eds), Shakespeare in the Worlds of Communism and Socialism, Toronto, University of Toronto Press, 2006, p.120. 
4. Arthur Mendel, "Hamlet and Soviet Humanism", Slavic Review, Vol. 30, No. 4, December, 1971, 733-747, at p.733.

5. Bevington, op. cit., loc. cit.

6. Laurence Senelick and Sergei Ostrovsky, The Soviet Theatre: A Documentary History, New Haven and London, Yale University Press, 2014, p. 478.

7. See, for example, "Gastroli teatra imeni Leningradskogo soveta", Sovetskaia Belorussia, 16 June, 1939; Stepan Birillo, “'Gamlet', vmesto retsenzii”, Sovetskaia Belorussia, 23 June, 1939, p. 3; Kurortnaia gazeta Sochi, 10 September, 1940 (about the start of the Radlov Theatre's tour and its successful performance of Hamlet); "K gastroliam teatra imeni Leningradskogo Soveta", Krasnoe znamia (Sochi), 6 September, 1940; M. Senin, 'Gamlet: spektakl' teatra im. Leningradskogo soveta', Kurortnaia Gazeta G. Sochi, 15 September, 1940.

8. Solomon Volkov, Testimony, London, Hamish Hamilton, 1979, p. 64-65.

9. See Laurel Fay's comprehensive refutations in Malcolm H. Brown (ed.), A Shostakovich Casebook, Bloomington, Indiana University Press, 2004, p. 11-66.

10. Anatoly Smeliansky, The Russian Theatre after Stalin, Cambridge, Cambridge University Press, 1999, p. 6.

11. Ibid.

12. Nikolai Chushkin, Gamlet-Kachalov, Moscow, Iskusstvo, 1966, p. 309; quoted in Mendel, op. cit., p. 734-735.

13. Ibid.

14. B. Arutiunian, "Virmenskii teatr", in Inna Vishnevskaia (ed.), Istoriia sovetskogo dramaticheskogo teatra $v$ shesty tomakh, vol. 5: 1941-1953, Moscow, Nauka, 1969, p. 333-364, at p. 342.

15. Kindly confirmed by Ksenia Iasnova from the research centre of the archive of the Moscow Art Theatre, email communication, 29 January 2016.

16. Dmitri Urnov, "Kak Stalin Gamleta zapretil”, Nash sovremenik, 2, 2012, 218-237, also available at http://nash-sovremennik.ru/archive/2012/n2/1202-19.pdf, accessed 3 October 2016. Urnov sent me an unabridged version of his article - email communication, 19 July 2015 - and some of the information provided below comes from this latter version.

17. The anecdote was later published by the actor's son, Vasilii Livanov, Nevydumannyi Boris Pasternak, Moscow, Drofa, 2002, p. 87-91.

18. Urnov, op.cit. p. 218 (the following quotes are from Urnov's published article unless otherwise stated).

19. Semenenko, op. cit., p. 157; Isaiah Berlin, Personal Impressions, Princeton, Princeton University Press, New Expanded Edition, 2001, p. 229-230.

20. Semenenko, op. cit., p. 157.

21. Nemirovich-Danchenko's directorial concepts and work on Hamlet are partly documented in Vladimir Nemirovich-Danchenko and Vitalii Vilenkin, Nezavershennye rezhisserskie raboty: Boris Godunov, Gamlet, Moscow, VTO, 1984.

22. "Dokumenty sobrannye A.I. Katsmanom o postanovkakh p'es angliskikh avtorov. T.7. 0 postanovkakh p'es U. Shekspira. Chast' 2. O postanovkakh p'esy 'Gamlet' (stat'i, retsenzii, ... iz izdanii 1935-1955 godov)”, TsGALI, f. 563, op. 1, ed. khr. 180, 27 and 27 verso.

23. "Blizhaishee primeri khudozhestvennogo teatra", Literatura i iskusstvo, 30 June 1943, quoted in Livanov, Liudi i kukli, Moscow, Astrel', 2012, 60, also available at http://www.litmir.co/br/? $\mathrm{b}=186132 \& \mathrm{p}=60$, accessed 22 May 2016.

24. Urnov, op.cit.

25. Ibid.

26. Semenenko, op. cit., p. 148. Pasternak's translations of Shakespeare in general, and of Hamlet in particular, have been widely studied. See, for example, Anna Kay France, Boris Pasternak's Translations of Shakespeare, Berkeley, Los Angeles and London, University of California Press, 1978. 
27. Alisa Shebalina, V.Ia. Shebalin: Gody zhizni i tvorchestva, Moscow, Sovetskii kompozitor, 1990, p. 129.

28. Benedikt Sarnov (ed.), Stalin i pisateli, Moscow, Eksmo, 2008, p. 243.

29. Semenenko, op. cit., p. 158.

30. "Authorized transcript of the conversation between I.V. Stalin, A.A. Zhdanov, and V.M. Molotov, and S.M. Eisenstein and N.K. Cherkasov, concerning Ivan the Terrible. 26 February 1947", in D. Mar'iamov, Kremlevskii tsenzor: Stalin smotrit kino, Moscow, Kinotsentr, 1992, 84-92; quoted in Evgeny Dobrenko and Katerina Clark (eds), Soviet Culture and Power, New Haven and London, Yale University Press, p. 440-445.

31. Ibid., p. 441.

32. Ibid.

33. Katerina Clark, "Sergei Eisenstein's Ivan the Terrible and the Renaissance: Ivan the Terrible an Example of Stalinist Cosmopolitanism?", Slavic Review, 71/1 (Spring 2012), p. 49-69, at p.59-62.

34. Semenenko, op. cit., p. 159.

35. Molotov at the Kremlin meeting of 26 February 1947, quoted in Dobrenko and Clark, op. cit., p. 441.

36. Clark, op. cit., p. 62.

37. Sergei Eisenstein and Richard Taylor (ed.), The Eisenstein Reader, London, BFI, 1998, p. 161.

38. Dobrenko and Clark, op. cit., p. 447.

39. For the first and the third (on cinema), see ibid., p. 402-403.

40. Ibid., p. 392.

41. Dobrenko, "Literary Criticism and the Institution of Literature in the Era of War and Late Stalinism 1941-1953", in Dobrenko and Tihanov (eds), A History of Russian Literary Theory and Criticism, Pittsburg, University of Pittsburg Press, 2011, p. 170.

42. "The dramatic repertoire and measures to improve it: Decision of the Central Committee, CPSU (b), 26 August 1946", in Decisions of the Central Committee CPSU (b) on Literature and Art (1946-1948), Moscow, Foreign Languages, 1951, 11-20; quoted in Senelick and Ostrovsky, The Soviet Theater, op. cit., p. 484.

43. Ibid.

44. Ibid., p. 483.

45. Dobrenko, op. cit., p.171.

46. Zdeněk Stříbrný, Shakespeare and Eastern Europe, Oxford, Oxford University Press, 2000, p. 97.

47. George Gibian, "Shakespeare in Soviet Russia", The Russian Review, 11/ 1 (January 1952), p. 33.

48. Mikhail Morozov, Shakespeare on the Soviet Stage, London, Soviet News, 1947.

49. See, for example, the multi-volume history of Soviet theatre: Inna Vishnevskaia et al. (eds), Istoriia sovetskogo dramaticheskogo teatra $v$ shesty tomakh, Vol. 5: 1941-1953.

50. Makaryk, op. cit., p.123.

51. Vishnevskaia, Istoriia sovetskogo dramaticheskogo teatra, op. cit., p. 269.

52. Liubov' Vendrovskaia, "Rabota Kabineta Shekspira VTO", in Mikhail Morozov et al. (eds), Shekspirovskii sbornik 1947, Moscow, VTO, 1948, 254-263, here p. 258.

53. RGALI, f. 2420 , op. 1, ed. khr. 67. No further detail regarding the music appears in any of the consulted material; however, it was most probably by Nikolai Rakhmanov (1892-1964) who was a theatre composer and conductor.

54. "Protokol: obsuzhdenie raboty A.N. Glumova v VGKO ot 13 Fev 1946", RGALI, f. 2420, op. 2, ed. khr. 7.

55. Timothy Sergay, “Boris Pasternak's ‘Christmas Myth': Fedorov, Berdiaev, Dickens, Blok”, PhD dissertation, University of Yale, 2008, p. 131.

56. Ibid., p.132.

57. Birgit Beumers, Yuri Lyubimov at the Taganka Theatre 1964-1994, p. 115. 
58. For statistics derived from the list of Shakespeare productions on Soviet stage (1945-1957) published in the 1958 issue of Shekpirovskii sbornik, see http://www.w-shakespeare.ru/library/ shekspirovskiy-sbornik26.html, accessed 12 May 2016.

59. See Ekaterina Vlasova, 1948 God v sovetskoi muzyke, Moscow, Klassika-Kh.Kh.T, 2010.

60. See Dobrenko, "Literary criticism and the institution of literature", op. cit., p.175.

61. Morozov et al. (eds), Shekspirovskii sbornik, VTO, Moscow, 1947.

62. Morozov, "Falsifikatory Shekspira", Teatr (January 1949), p. 53-56; “Teatrovedecheskaia ekspansiia Uall Strita", Teatr (May 1949), p. 85-88.

63. For a bibliography of Shakespeare-related publications, see I.M. Levidova, Shekspir: Bibliografiia russkikh perevodov i kriticheshkoi literatury na russkom iazyke 1748-1962, Moscow, Kniga, 1964, also at http://az.lib.ru/s/shekspir_w/text_0220.shtml, accessed 21 May 2016.

64. See Mark Sokolianskii, "Osnovnye tendentsii v otechestvennom shekspirovedenii 1960-1980ikh godov", in G. Krasnov and A. Viktorovich (eds), Iz istorii filologii: sbornik statey i materialov: k 85letiiu G.V. Krasnova, Kolomna KTPI, p. 72-83.

65. The term probably entered Western writings through Chushkin's use of it in Gamlet-Kachalov, 309, quoted in Mandel, "Hamlet and Soviet Humanism", p. 734.

66. Aleksei Bartoshevich, "Gamlety nashikh dnei”, in Bartoshevich (ed.), Shekspirovskie chteniia, Moscow, Moscow Humanitarian University Press, 2010, p. 209-216.

67. See, for example, David Sillito, "Hamlet: The Play Stalin Hated", BBC, 22 April, 2012 (on a Lithuanian production of Hamlet on tour to the UK, in the context of the "Globe to Globe" project), http://www.bbc.co.uk/news/magazine-17770170, accessed 26 November 2015.

68. Ibid.

69. The general syndrome has long since been recognised - see, for example, Katerina Clark, The Soviet Novel: History as Ritual, Chicago, University of Chicago Press, 1981; Clark, Petersburg, Crucible of Cultural Revolution, Cambridge MA, Harvard University Press, 1995; Clark, Moscow, the Fourth Rome: Stalinism, Cosmopolitanism, and the Evolution of Soviet Culture, 1931-1941, Cambridge, MA, Harvard University Press, 2011; Sheila Fitzpatrick, Everyday Stalinism: Ordinary Life in Extraordinary Times: Soviet Russia in the 1930s, New York, Oxford University Press, 1999; Fitzpatrick, Stalinism: New Directions, London, Routledge, 2000.

70. Alexei Bartoshevich has repeatedly referred to the image of mirror in his writings, lectures and interviews about Hamlet - see, for example, "Gamlety nashikh dnei", in Karina MelikPashaeva (ed.), Teatr, Zhivopis', muzyka, Kino: Ezhekvartal'nyi al'manakh, No. 4, Moscow, GITIS, 2010, p. 9-21, here p. 20.

71. Reginald A. Foakes, Hamlet versus Lear: Cultural Politics and Shakespeare's Art, Cambridge, Cambridge University Press, 1993, p. 20.

72. Ibid.

73. Aleksei Semenenko, Hamlet the Sign: Russian Translations of Hamlet and Literary Canon Formation, Stockholm, Stockholm University, 2007, p. 140.

74. For an analysis of this production, see Michelle Assay, "Akimov and Shostakovich's Hamlet: a Soviet 'Shakesperiment", Actes des congrès de la Société française Shakespeare, 33 (2015), http:// shakespeare.revues.org/3329, accessed 22 May 2016.

75. The best-known example of this was Sergei Radlov's 1938 production in Leningrad.

76. The notions of Hamletism in general and Russian Hamletism in particular have been discussed in several studies - see, for example, Boris Gaydin, "Obraz Gamleta na otechestvennom ekrane vtoroi poloviny XX - nachala XXI veka", Znanie. Ponimanie. Umenie (2013/4), p. 170-182. 


\section{ABSTRACTS}

Soon after its arrival in a Russia in 1748, Hamlet and its chief protagonist became inseparable parts of Russian national identity, prompting such remarks as William Morris's: "Hamlet should have been a Russian, not a Dane". However, at the outbreak of the Second World War, the play seems to have disappeared for more than a decade from the major stages of Moscow and Leningrad. Thus was born the 'myth' of Stalin and Hamlet. Today virtually every mention of Hamlet in the Stalin era refers to the dictator's hatred for this tragedy and his supposed banning of it from all Soviet stages. Notwithstanding the efforts of theatre directors such as Sergei Radlov with his heroic production of Hamlet in 1938, there is no doubt that Hamlet was problematic in the context of the paradigm of Socialist Realism. And it was certainly not the most suitable play for a war-stricken country. Moreover, from Stalin's own pejorative reference to 'an indecisive Hamlet' in connection with Eisenstein's ill-fated depiction of Ivan the Terrible (Part II), it is evident that for the dictator the character of Hamlet had negative connotations. The chequered history of Hamlet in the Soviet Union from the outbreak of the War to the death of Stalin in 1953 and the flood of new productions almost immediately after this date, together with the myth of Stalin's 'ban', deserve more nuanced and broadly contextualised study than they have received to date, based on concrete historical facts, memoirs and official documents.

Peu après son arrivée en Russie en 1748, Hamlet (et son personnage principal) devient inséparable de l'identité nationale russe, au point de faire dire à William Morris : "Hamlet aurait dû être russe, pas danois ». Pourtant, lorsque éclate la Seconde Guerre Mondiale, la pièce semble avoir disparu depuis plus d'une décennie des scènes principales à Moscou et à Leningrad. Ainsi est né le «mythe" de Staline et Shakespeare. La grande majorité des études consacrées à Hamlet pendant l'ère stalinienne mentionnent la haine du dictateur à l'égard de cette tragédie et l'interdiction de sa représentation qu'il aurait imposée sur toutes les scènes soviétiques. Malgré les efforts (parfois héroïques) de metteurs en scène comme Sergueï Radlov en 1938, Hamlet pose indubitablement problème par rapport au paradigme du Réalisme socialiste. En outre, ce n'est sans doute pas la pièce la plus adéquate pour un pays en guerre. Enfin, la référence péjorative de Staline à « l'indécision » de Hamlet à propos de l'infortunée représentation d'Ivan le Terrible par Eisenstein (IIe partie) montre clairement que le personnage de Hamlet avait des connotations négatives pour le dictateur. L'histoire en dents de scie de la réception de Hamlet en Union Soviétique du début de la guerre à la mort de Staline en 1953 (suivie immédiatement d'un déluge de nouvelles mises en scène), ainsi que le mythe de son «interdiction » par Staline, doivent recevoir un traitement plus nuancé que celui qui leur est habituellement réservé, fondé sur l'étude de faits historiques concrets, de mémoires et de documents officiels.

\section{INDEX}

Mots-clés: Eisenstein Sergueï, Ivan le Terrible, Pasternak Boris, Shakespeare en Union Soviétique, Staline et Hamlet, Théâtre d'Art de Moscou

Keywords: Eisenstein Sergei, Ivan the Terrible, Myth of Stalin and Hamlet, Moscow Art Theatre, Pasternak Boris, Soviet Shakespearology 
AUTHOR

MICHELLE ASSAY

Université Paris Sorbonne, University of Sheffield 